\title{
Five-Year Mortality among Americans Incarcerated in Privatized Versus Public Prisons: the Mortality Disparities in American Communities Project
}

$\mathrm{J}$ Gen Intern Med

DOI: $10.1007 / \mathrm{s} 11606-020-06057-\mathrm{w}$

() Society of General Internal Medicine 2020

\section{BACKGROUND}

Since the 1970s, the number of incarcerated Americans has tripled, creating a significant financial burden on states. To reduce costs, states increasingly rely on privatized prisons. Nationally, privatized prisons have grown by $39 \%$ since the year 2000 , managing $8.2 \%$ of the country's prison population. ${ }^{1}$

There is great variation in the quality of healthcare between privatized and public correctional institutions, and privatized prisons may be incentivized to reduce healthcare services in order to maximize profit. ${ }^{2}$ However, little research has been done to evaluate disparities in health outcomes. One study found fewer health services were available in privatized prisons. ${ }^{2}$ Another study using data from before 1990 suggested an increase in mortality associated with the privatization of correctional healthcare. ${ }^{3}$ Conversely, in 2016, the Department of Justice issued a review that found fewer per capita deaths within privatized prisons, though potential confounders were not considered. ${ }^{4}$ No recent study has looked at how longer-term mortality is affected by exposure to incarceration in the privatized prison setting.

\section{OBJECTIVE}

We aimed to measure whether privatized prisons are associated with mortality. We hypothesized that privatized prisons were associated with higher rates of long-term mortality compared with public prisons.

\section{METHODS AND FINDINGS}

We used data from the Mortality Disparities in American Communities study (MDAC), a national project of the United States Census Bureau, to estimate factors that lead to mortality disparities. The MDAC database is a record linkage of the 2008

Received February 10, 2020

Accepted July 13, 2020
American Community Survey (ACS) to the National Death Index (NDI). ${ }^{5}$ In accordance with Census Bureau standards, after survey weights were applied, cells were rounded to the nearest ten.

Our cohort included respondents aged 18 and older who identified a verified state or federal prison as their current residence $(N=26,500)$. Federal detention centers, correctional residential facilities, and military disciplinary units were not included in our analyses.

The independent variable was detention in a privatized versus public prison. The primary outcome was all-cause mortality through five years from time of interview (2013). Additional individual-level covariates included demographics (age, sex, race, Hispanic ethnicity), social covariates (place of birth, mobility status [same address as 1 year ago versus not], educational attainment, and marital status) and disability status, and prison-level covariates (prison size $[<500$ people versus $\geq 500$ ], a binary crowding indicator, and security level) obtained from the 2005 Census of State and Federal Adult Correctional Facilities.

We tabulated sociodemographic characteristics by prison type. Next, we reported the age-stratified unadjusted death rates and 95\% confidence intervals. Finally, we conducted tiered adjusted Cox proportional hazard models to test for the independent association between prison type and mortality. The first model adjusted for demographic characteristics, the second model additionally adjusted for social covariates and disability status, and the final model additionally adjusted for prison-level covariates. We considered an association significant for a $p$ value $<0.05$, using a 2-tailed test, and calculated $95 \%$ confidence intervals.

The unweighted sample consisted of 25,000 respondents in public prison and 1500 in privatized prison, which was overwhelmingly male and disproportionately black (Table 1 ). The average age was 36.8 years (IQR, 28-44). Respondents in privatized prisons were more likely to be of Hispanic ethnicity and non-US-born compared with those in public prisons.

The unadjusted death rate at five-year follow-up in all categories was higher among those incarcerated in public prisons compared with privatized prisons (Table 2). In the proportional hazards model adjusted for demographics, the adjusted hazards ratio (aHR) among those in privatized prisons was $0.63(95 \%$ CI, $0.40-0.97 ; p=0.03$ ). After adjustment for social 
Table 1 Demographics of Respondents Residing in State and Federal Prisons by Type of Correctional Facility in 2008, Mortality Disparities in American Communities

\begin{tabular}{|c|c|c|c|c|c|}
\hline & \multicolumn{2}{|c|}{$\begin{array}{l}\text { Public } \\
(N=25,000)\end{array}$} & \multicolumn{2}{|l|}{$\begin{array}{l}\text { Privatized } \\
(N=1500)\end{array}$} & \multirow[t]{2}{*}{$\begin{array}{l}p \\
\text { value }\end{array}$} \\
\hline & $\begin{array}{l}\text { Weighted, } \\
N\end{array}$ & $\%$ & $\begin{array}{l}\text { Weighted, } \\
N\end{array}$ & $\%$ & \\
\hline \multicolumn{5}{|l|}{ Age category } & \multirow[t]{6}{*}{0.09} \\
\hline $18-29$ & 343,900 & 31.5 & 21,380 & 31.7 & \\
\hline $30-39$ & 326,400 & 29.9 & 21,900 & 32.5 & \\
\hline $40-49$ & 270,000 & 24.7 & 15,820 & 23.5 & \\
\hline $50-59$ & 115,600 & 10.6 & 6623 & 9.8 & \\
\hline$\geq 60$ & 35,290 & 3.2 & 1627 & 2.4 & \\
\hline \multicolumn{5}{|l|}{ Sex } & \multirow[t]{3}{*}{0.91} \\
\hline Male & $1,001,000$ & 91.7 & 61,730 & 91.7 & \\
\hline Female & 90,090 & 8.3 & 5617 & 8.3 & \\
\hline \multicolumn{5}{|l|}{ Race } & \multirow[t]{4}{*}{$\begin{array}{l}< \\
0.001\end{array}$} \\
\hline White & 559,600 & 51.3 & 38,490 & 57.2 & \\
\hline Black & 461,800 & 42.3 & 24,780 & 36.8 & \\
\hline Other & 69,950 & 6.4 & 4072 & 6.0 & \\
\hline \multicolumn{5}{|l|}{$\begin{array}{l}\text { Hispanic } \\
\text { ethnicity }\end{array}$} & \multirow[t]{3}{*}{$\begin{array}{l}< \\
0.001\end{array}$} \\
\hline Hispanic & 209,400 & 19.2 & 20,570 & 30.5 & \\
\hline Not Hispanic & 881,800 & 80.8 & 46,770 & 69.5 & \\
\hline \multicolumn{5}{|l|}{ Place of birth } & \multirow{3}{*}{$\begin{array}{l}< \\
0.001\end{array}$} \\
\hline US-born & $1,009,000$ & 92.4 & 51,190 & 76.0 & \\
\hline Non-US-born & 82,620 & 7.6 & 16,150 & 24.0 & \\
\hline \multicolumn{5}{|l|}{ Mobility status } & \multirow[t]{4}{*}{0.19} \\
\hline Same address & 578,300 & 53.0 & 34,520 & 51.3 & \\
\hline $\begin{array}{l}\text { as } 1 \text { year ago } \\
\text { Diff. address }\end{array}$ & 513,000 & 47.0 & 32,820 & 48.7 & \\
\hline $\begin{array}{l}\text { from } 1 \text { year } \\
\text { ago }\end{array}$ & & & & & \\
\hline \multirow{2}{*}{\multicolumn{5}{|c|}{$\begin{array}{l}\text { Educational } \\
\text { attainment }\end{array}$}} & \multirow{5}{*}{$\begin{array}{l}< \\
0.001\end{array}$} \\
\hline & & & & & \\
\hline Less than HS & 412,600 & 37.8 & 28,310 & 42.0 & \\
\hline $\begin{array}{l}\text { HS grad or } \\
\text { equivalent }\end{array}$ & 442,600 & 40.6 & 27,280 & 40.5 & \\
\hline $\begin{array}{l}\text { Some college } \\
\text { and higher }\end{array}$ & 236,000 & 21.6 & 11,750 & 17.4 & \\
\hline \multicolumn{5}{|l|}{ Marital status } & \multirow[t]{7}{*}{0.007} \\
\hline Married & 191,200 & 17.5 & 13,920 & 20.7 & \\
\hline Widowed & 21,300 & 2.0 & 1090 & 1.6 & \\
\hline Divorced & 203,400 & 18.6 & 11,910 & 17.7 & \\
\hline Separated & 53,790 & 4.9 & 3920 & 5.8 & \\
\hline Never & 621,500 & 57.0 & 36,510 & 54.2 & \\
\hline \multirow{2}{*}{\multicolumn{5}{|c|}{$\begin{array}{l}\text { married } \\
\text { Disability }\end{array}$}} & \\
\hline & & & & & \multirow{4}{*}{$\begin{array}{l}< \\
0.001\end{array}$} \\
\hline status & & & & & \\
\hline Any disability & 268,500 & 24.6 & 13,520 & 20.0 & \\
\hline No disability & 822,800 & 75.4 & 53,803 & 80.0 & \\
\hline
\end{tabular}

${ }^{1}$ Census Bureau Disclosure Release Board Numbers: CBDRB-FY19436; CBDRB-FY19-567; CBDRB-FY19-449; CBDRB-FY20-108

characteristics, the aHR was 0.62 (95\% CI, 0.40-0.96; $p=$ 0.02 ). Adjusted additionally for prison-level characteristics, the aHR was 0.57 (95\% CI $0.37-0.89 ; p=0.01)$.

\section{DISCUSSION}

In this nationally representative sample of incarcerated Americans, we found those incarcerated in privatized prisons experienced lower five-year mortality rates than those in public prisons. This finding is surprising because privatized prisons are incentivized to provide lower-quality healthcare, but may be due to the fact that
Table 2 Five-Year Mortality Rate of Individuals Located in Privatized Compared with Publicly Managed Prisons (2008-2013)

\begin{tabular}{lll}
\hline \hline & Public & Privatized \\
\hline Unadjusted death rate per & $264(95 \%$ CI & $136(95 \%$ CI 119- \\
100,000 (18-34 years) & $258-270)$ & $156)$ \\
Unadjusted death rate per & $661(95 \%$ CI & $372(95 \%$ CI, \\
100,000 (35-64 years) & $652-671)$ & $343-402)$ \\
Unadjusted death rate per & $3843(95 \%$ CI & $2747(95 \%$ CI \\
100,000 (65+ years) & $3702-3988)$ & $2193-3400)$ \\
Model 1 $1^{\mathrm{a}}$ aHR (95\% CI) & REF & $0.63(0.40-0.97)$ \\
Model 2b aHR (95\% CI) & REF & $0.62(0.40-0.96)$ \\
Model 3 3 aHR (95\% CI) & REF & $0.57(0.37-0.89)$ \\
\hline
\end{tabular}

${ }^{a}$ Adjusted for age, sex, race, ethnicity

${ }^{b}$ Adjusted for age, sex, race, ethnicity, education, marital status, disability, region, and mobility

${ }^{c}$ Adjusted for age, sex, race, ethnicity, education, marital status, disability, region, mobility, prison crowding, and prison security level

${ }^{I}$ Census Bureau Disclosure Release Board Numbers: CBDRB-FY19436; CBDRB-FY19-567; CBDRB-FY19-449; CBDRB-FY20-108; CBDRB-FY20-CESO04-018

privatized prisons can select occupants based on health status. ${ }^{6}$ Our findings are limited by the lack of data on incarceration status during the follow-up period. Future studies should explore why privatized prisons may be associated with lower rates of death and how the provision of healthcare by privatized and public institutions impact mortality.

Laura Hawks, $M D^{1,2}$

Candace Cosgrove, $\mathrm{MPH}^{3}$

Mathew Neiman, $\mathrm{MS}^{3}$

Brita Roy, MD, MPH, MHS ${ }^{4}$

Christopher Wildeman, $\mathrm{PhD}^{5}$

Sean Coady, MS, $M A^{6}$

Emily A. Wang, MD, MAS ${ }^{4}$

${ }^{1}$ Department of Medicine, Cambridge Health Alliance, Cambridge, MA, USA

${ }^{2}$ Harvard Medical School,

Boston, MA, USA

${ }^{3}$ Mortality Research Branch, Center for Economic Studies, US Census Bureau,

Bethesda, MD, USA

${ }^{4}$ Division of General Medicine, Yale School of Medicine,

New Haven, CT, USA

${ }^{5}$ Department of Policy Analysis and Management, Cornell University,

Ithaca, NY, USA

${ }^{6}$ National Heart, Lung, and Blood Institute,

Bethesda, MD, USA

Corresponding Author: Laura Hawks, MD; Department of Medicine, Cambridge Health Alliance Cambridge, MA, USA (e-mail: lhawks@hsph.harvard.edu).

Funding Information Dr. Hawks received funding support from an Institutional National Research Service Award from T32HP32715 and by the Cambridge Health Alliance. Dr. Roy receives research funding from the NIH National Heart, Lung, and Blood Institute, and is a consultant for the Institute for Healthcare Improvement's 100 Million Healthier Lives initiative. 


\section{Compliance with Ethical Standards:}

These results have been reviewed by the Census Bureau's Disclosure Review Board (DRB) to ensure that no confidential information is disclosed. The DRB release numbers are the following: CBDRB-FY19436; CBDRB-FY19-567; CBDRB-FY19-449; CBDRB-FY20-108; CBDRB-FY2O-CESOO4-018.

Conflict of Interest: The authors declare that they do not have a conflict of interest.

Disclaimer: This paper is released to inform interested parties of research and to encourage discussion. Any views expressed in this manuscript on statistical, methodological, technical, or operational issues are those of the authors and not do not necessarily represent the views U.S. Census Bureau, the National Heart, Lung, and Blood Institute; the National Institutes of Health; or the U.S. Department of Health and Human Services.

\section{REFERENCES}

1. The Sentencing Project. Private Prisons in the United States https://www. sentencingproject.org/wp-content/uploads/2017/08/Private-Prisons-inthe-United-States.pdf. Published October 2019. Accessed 19 Nov 2019.

2. Baćak V, Ridgeway G. Availability of health-related programs in private and public prisons. J Correct Health Care 2018;24(1):62-70.

3. Bedard K, Frech III H. Prison health care: is contracting out healthy? Health Econ 2009; 18(11):1248-1260.

4. Office of the Inspector General. Review of the Federal Bureau of Prisons monitoring of contract prisons. US Department of Justice Washington, DC. https://oig.justice.gov/reports/2016/e1606.pdf. Published 2016. Accessed 19 August 2019.

5. The United States Census Bureau. Mortality Disparities in American Communities: Project Overview https://www.census.gov/mdac. Published 21 June 2019. Accessed 19 Aug 2019.

6. Petrella C. The color of corporate corrections, part II: Contractua exemptions and the overrepresentation of people of color in private prisons. Radic Criminol 2013(3).

Publisher's Note: Springer Nature remains neutral with regard to jurisdictional claims in published maps and institutional affiliations. 


\section{AUTHOR QUERIES}

\section{AUTHOR PLEASE ANSWER ALL GUERIES.}

Q1. Please check the suggested running page title if appropriate. Otherwise, please provide short running title with maximum of 65 characters including spaces.

Q2. Please check and confirm if the authors and their respective affiliations are correctly identified and amend if necessary.

Q3. Please check if the captured funding information is correct.

Q4. Please provide Conflict of Interest statement for this article.

Q5. Please check if the captured statements under "Compliance with ethical standards" and "Disclaimer" are appropriate. 